\title{
Explaining the Selection and Rejection of Harriet Miers: George W. Bush, Political Symbolism, and the Highpoint of Conservatism
}

\author{
Kevin J. McMahon
}

Following the retirement of Justice Sandra Day O'Connor and the death of Chief Justice William Rehnquist in the summer of 2005, President George W. Bush appeared to be in alliance with conservatives in his desire to fill the two vacancies with strong ideologues who would push the Supreme Court to the right. However, after pleasing conservatives with his selection of John Roberts for one of the vacancies, President Bush angered many of his ideological brethren by choosing White House counsel Harriet Miers for the other. This article considers why the president decided on Miers and why her selection upset so many conservatives. It concludes by suggesting that Miers's forced withdrawal represented a highpoint in the conservative effort to transform the Court.

On a typically humid late summer evening in the environs of the nation's capital, William Hubbs Rehnquist - the 16th Chief Justice of the United States - succumbed to his struggle with illness and age. The date was September 3, 2005. At that moment, the Rehnquist Court-in place for nearly twenty years - came to an end. Shortly thereafter, commentators began to reflect on the successes and failures of this Court, constructed mainly by Republican presidents from the right to pursue conservative ends. To most, while the Rehnquist years represented a clear advance of the chief justice's conservative principles, the Court ultimately fell short of announcing an ideologically consistent doctrine.

In considering the limited nature of the Rehnquist Court's conservatism, scholars from both ends of the ideological spectrum have focused on the divide among its Republican-appointed members. For example, Mark Tushnet-a constitutional scholar from the left—argues that the "two types of Republican” justices drove this result (2005). As Tushnet (2005) writes, the Rehnquist Court's "divisions meant that conservatives prevailed-more or less-on issues associated with the Republican Party's effort to scale down the size of government, while losing rather consistently on the social issues - abortion, gay rights, and affirmative action - that animated an important part of the party's base.” Tushnet adds, social conservatives' "actual accomplishments have been meager because they have been thwarted, not by activist liberals or by Democrats but by Republicans uneasy about the Republican cultural agenda” (Tushnet 2005, 9-11; see also, Keck 2007). In

KEVIN J. MCMAHON is an associate professor of political science at Trinity College

The American Review of Politics, Vol. 29, Fall, 2008: 253-270

(C)2008 The American Review of Politics 
analyzing six—largely social—-battleground issues,” Richard E. Morgana constitutional scholar from the right-largely agrees with Tushnet's conclusions about the extent of the social conservative failure and its political origins (2006). Morgan (2006) even puts a date on the conservative demise: June 29, 1992. "On that day the long-awaited decision in Planned Parenthood $v$. Casey was handed down, explicitly reaffirming the core holding of Roe $v$. Wade," that a woman has a constitutional right to terminate an unwanted pregnancy. "With this decision," he concludes, "the conservative constitutional insurgency ... ended in a virtual rout." To Morgan, the reason for this result was fairly clear. "The blame belongs mainly to the presidents who nominated the Rehnquist Court's wavering justices” (Morgan 2006, [emphasis added]).

President George W. Bush apparently agreed with such assessments about the Rehnquist's Court doctrinal product. Thus, in the summer of 2005, first after Justice Sandra Day O'Connor announced her retirement in early July and then with Rehnquist's death two months later, the president sought to rectify the situation by filling the two vacancies with unflinching conservatives. According to journalist Jan Crawford Greenburg (2007), with his first chance to shape the Court, President Bush was almost obsessed with avoiding the mistake his father had made fifteen years earlier, when the elder Bush selected the stealthy David Hackett Souter of New Hampshire to fill the seat of the legendary liberal, Justice William Brennan (2007, 241-42). Despite assurances from chief of staff and former Granite state governor John Sununu that Souter was a rock solid conservative, soon after he joined the Court it became clear that the new justice was nothing of the sort. Instead, he emerged as a reliable liberal. Conservatives, who had been told to trust the president's choice, were not pleased. In fact, as Greenburg (2007) notes, they consider the Souter nomination "one the most inept political decisions of any modern-day president” $(2007,265)$. Even before he became president, George W. Bush set out to distinguish himself from his father's "mistake" by identifying the Court's two most conservative members, Justices Antonin Scalia and Clarence Thomas, as models to guide his own selections (Apple 2000).

In the summer and autumn of 2005, conservative leaders also saw clear inadequacies in constitutional doctrine. And like the president, they wanted nominees who fit the mold of the Court's most conservative members, socalled movement conservatives. To them, some of the most recent Republican nominees - namely, O'Connor, Souter, and Justice Anthony Kennedyhad been clear failures, pretenders to the declared conservative revolution in constitutional law. "As nominees, these justices had been sold to the Republican ranks as "confirmable" conservatives. But, in the end, they did not deliver the style of doctrine conservatives desired most. In 2005, with 
Republicans in control of the Senate and a conservative in the White House, most assumed the jurists chosen to replace O'Connor and Rehnquist would be much different; most assumed they would be ideologically reliable conservatives whom Republican senators-playing their role as advisors and consenters — could support with unbound enthusiasm.

But, as we know, all did not go as planned. In this article, I consider what happened and ask why. More specifically, I consider three questions. Why did President Bush decide on Harriett Miers to fill (for the second time) the seat of the retiring Sandra Day O'Connor? Why did many conservatives object so forcefully to her nomination? And what does this astonishing rejection of a president's nominee for the Court by members of his own party say about the state of conservatism at the time of the Miers nomination? In order to answer these questions, I suggest that it is essential to understand the events surrounding the selection of the so-called wavering Rehnquist Court justices. After examining these three nominations, I explore why President Bush was determined to pursue a different course but still ended up naming a nominee who outraged conservative activists. I conclude by suggesting that the forced withdrawal of the Miers nomination marked the highpoint in conservative confidence in altering the nation's highest tribunal since the election of Ronald Reagan in 1980.

\section{The Selection of "Wavering” Justices}

Conservative conclusions about the Republican-appointed "moderate" (or "wavering") justices are consistent with those offered by political scientists pursing the attitudinal approach to the study of judicial behavior. More specifically, both assess the success of a Supreme Court justice by focusing exclusively on ideology. So, for example, in writing about the Reagan legacy on the Court, attitudinalists Jeffrey Segal and Harold Spaeth write:

Few Presidents had the potential opportunity to influence the Supreme Court that Ronald Wilson Reagan did. The conservative Republican reached out again and again to social conservatives, calling for the return of school prayer and the overruling of Roe v. Wade. Fate smiled upon the fortieth President, granting him four appointees to the High Court and hundreds of appointees to the lower federal courts. Yet the Supreme Court he left was no more conservative than the one he inherited. Moreover, despite his appointments, the twentieth century ended with school prayer unconstitutional and Roe v. Wade the law of the land (Segal and Spaeth 2002, 217).

In making an ideological-based case about the Rehnquist Court, both legal commentators and attitudinal scholars suggest an inconsistency between the desires of the Republican political order and the doctrinal product; namely, as suggested above, that the Court failed to live up to conservative 
expectations. However, it is important to understand that presidents are rarely focused solely on ideology when selecting a nominee for the Court. More often than not, other political and electoral factors come into play. Put another way, overemphasizing ideology can be problematic for understanding the work of the Rehnquist Court since the Republican presidents (i.e., Ronald Reagan and George H.W. Bush) responsible for selecting O'Connor, Kennedy, and Souter were not only motivated by ideological factors when they made these choices. In this sense, in assessing presidential selections to the Court, it is important to understand the complexity of the political regime to which a president belongs. ${ }^{2}$ After all, while the president and other regime leaders will be committed to advancing a particular ideology, they will also be concerned about the ramifications of an unbending pursuit of those ideals. And indeed, it was quite apparent at the time of their appointments that these three nominees were not movement conservatives. Instead, as Segal shows, they were widely considered more moderate than Reagan and Bush's other-more clearly ideological-choices. For these three, the perceived ideological scores - ranging from 0 (most conservative) to 1 (most liberal) were: O’Connor (.415), Kennedy (.365), and Souter (.325). In contrast, the scores for the other Reagan and Bush nominees were: Rehnquist (.045), Antonin Scalia (.000), Robert H. Bork (.095), Douglas Ginsburg (.000), and Clarence Thomas (.160). ${ }^{3}$

An analysis of President Reagan's choice of O'Connor and Kennedy and George H.W. Bush's choice of Souter suggests two reasons-each linked to a desire for electoral gain and a comparatively uncomplicated confirmation-were primarily at play in making these selections. First, at the time of these three nominations, the evidence suggests that both Reagan and Bush were concerned about naming a jurist thought to be too far to the right. Such a choice might have excited and activated the Republican Party's base, but it also threatened to offend party moderates and independent voters, particularly if the confirmation attracted widespread media attention that portrayed the president as a slave to ideological zealots. As journalist Howard Fineman noted about the confirmation battle over Robert Bork, "It reminds voters, baby boomers in particular, why there are things that they don't like about the Republican Party” (quoted in Gitenstein 1992, 330).

A second (often overlapping) reason why presidents - and more specifically Presidents Reagan and Bush — avoid a confirmation battle involves the cost of political capital. If a president has other legislative priorities at the top of his agenda or little desire to dramatically transform the Court, there are few reasons to make a controversial appointment. For example, President Clinton repeatedly spoke of appointing a leading liberal politician to the bench — such as New York Governor Mario Cuomo or Secretary of Interior Bruce Babbitt—but in the end other priorities took prominence. In similar 
terms, Presidents Truman, Kennedy, and Johnson (with one exception) took few risks with their Supreme Court selections, at times appointing jurists who were criticized as political cronies (Yalof 1999). With little reason to select a nominee likely to confront a Senate challenge, they instead choose candidates likely to win easy confirmation (McMahon 2007). With these three High Court appointments, Reagan and Bush followed a more cautious course as well. To be sure, the partisan makeup of the Senate was an important concern here. If the president's party controls the Senate, it is easier to secure the confirmation of a more ideological nominee. However, if divided government exists, such a nomination will likely face a more contentious confirmation process and more media scrutiny (see Nemacheck 2007; see also, Scherer 2005).

While Republicans did control the Senate in 1981, President Reagan was clearly not interested in selecting a strong ideologue to replace the retiring Potter Stewart on the Court at that time. Indeed, although Reagan's decisive victory in 1980 was apparently one for both the "old" Goldwater right and the "new" social conservative right, during his first term he angered many in the latter group by displaying a disinterest in advancing their agenda (in favor of his economic and military program). His decision to carry through with a late campaign promise to appoint the first woman to the Supreme Court was one reason why social conservative leaders were displeased. While these leaders knew of Reagan's pledge, many hoped, in part due to the limited pool of ideologically-appropriate qualified women, he would not settle this score with his first choice for the Court. But Reagan was thinking more in political and electoral terms when he made the selection. Indeed, the emergence of the gender gap as an electoral phenomenonwith Reagan capturing 8 percent more of the male vote than the female vote (Selzer, Newman, and Leighton 1997)—likely guaranteed that he would name a woman as his first nominee (see also, Perry 1991, 121-24; Biskupic 2005, 70-73).

True to some expectations, Reagan's choice did not live up to the ideological hopes of conservatives, in particular social conservatives. Sandra Day O'Connor, although supposedly a committed champion of judicial restraint and a supporter of Reagan's brand of "new" federalism, had endorsed the Equal Rights Amendment and as an Arizona legislator had once voted to liberalize state laws on abortion and to expand the availability of contraception. ${ }^{4}$ Even before the choice was made, conservatives denounced the possibility. On the morning of July 6, 1981, there was a flood of activity between the White House and conservatives on Capitol Hill. For example, Oklahoma senator Don Nickles and Illinois Congressman Henry Hyde called the White House charging that O'Connor was "unacceptable to prolifers." According to a memo about the call, Nickles "said that if Connor [sic] is 
nominated, he and other pro-family Republican Senators will not support the choice." After fielding calls from pro-life activists for several days, one White House staffer concluded, "the nomination of Judge O'Connor would trigger a nasty political protest against the President." ${ }^{, 5}$ Despite this building conservative dissent, Reagan nominated O'Connor the very next day, July 7, 1981. In response to the news, Republican Senator Jesse Helms of North Carolina said he was "skeptical" of the nomination. Moral Majority leader Jerry Falwell thought it was "a disaster." The National Right to Life Committee believed it was "a repudiation of the Republican platform," and pledged an all-out fight to block confirmation. At the other end of the ideological spectrum, Democratic Congressman Morris Udall of Arizona concluded that O’Connor was "about as moderate a Republican as you'll ever find being appointed by Reagan.” Massachusetts Senator Ted Kennedy declared the nomination "a major victory for women's rights" (all quotes appear in Witt 1986, 7).

With Senate Democrats in support of the nomination and Reagan working hard to bring conservatives in line, O'Connor sailed through the Senate without a dissenting vote, making her the first woman to don the High Court's black robes. Politically the Reagan White House considered the appointment a striking success. ${ }^{6}$ But to conservatives in the Reagan Justice Department, O'Connor later became 'known derisively as an '80 percenter.' Though generally conservative, she deserted the administration at crucial moments” (Savage 1992, 5).

Late in his second term, after the Senate rejected his selection of movement conservative Robert Bork and his replacement (Douglas Ginsburg) was forced to withdrawal from consideration, President Reagan decided against using more precious political capital by appointing another clear ideologue. Instead, he chose Anthony Kennedy, a nominee many considered to be another "80-percenter." As one reporter noted, "Reagan has finally yielded to the imperative of winning in the Senate. After the fiasco of Judge Douglas $\mathrm{H}$. Ginsburg, he had to abandon his preference for a tamper-proof ideologue in the Robert H. Bork image” (quoted in Massaro 1990, 196). Memos available at the Reagan Presidential Library document the concern in the administration about Kennedy's commitment to conservatism. For example, in a memo outlining Kennedy's jurisprudence, Steve A. Matthews, Deputy Assistant Attorney General for Judicial Selection, found that "some of the most disturbing aspects of Judge Kennedy's jurisprudence" were with his use of "novel claims of constitutional protection." Perhaps foretelling Kennedy's precedent-altering 2003 opinion in Lawrence v. Texas, Matthews highlighted the judge's opinion in Beller v. Middendorf. For Matthews, Kennedy's Beller opinion was somewhat alarming for two reasons. First, he "very grudgingly upheld the validity of naval regulations prohibiting 
homosexual conduct." And in doing so, he "stated the rule much more narrowly than either the Constitution or precedent required." Second, Kennedy "cited Roe v. Wade and other 'privacy right' cases very favorably and indicated fairly strongly that he would not uphold the validity of laws prohibiting homosexual conduct outside the context of the military.” To Matthews, "This easy acceptance of privacy rights as something guaranteed by the Constitution is really very distressing., ${ }^{7}$

While it is unknown whether President Reagan read this memo, it is clear that his administration was willing to look beyond conservative concerns about Kennedy. In turn, many who opposed Bork found Kennedy a refreshing alternative. For example, to the AFL-CIO's Lane Kirkland, "Judge Kennedy—in contrast to Judge Bork—show[ed] no sign of being attracted to eccentric and rigid theories of jurisprudence that would freeze the meaning of the Constitution by referring only to a simplified view of original intent.” Rather, Kirkland expected Kennedy to follow a more traditional style of judging, by examining "our historical experiences and our broadly held social values" to give "practical meaning and modern application" to "the Constitution's expansive civil rights and civil liberties guarantees” (quoted in Maltz 2003, 141-42). Leading social conservatives focused on transforming the courts were not so pleased. For example, longtime conservative activist Richard Viguerie considered the nomination "a total surrender to the left” (quoted in Greenhouse 1987). But with natural opponents to the Reagan White House like Kirkland expressing support and Republican senators standing by their president, Kennedy easily won confirmation.

With the retirement of Justice William Brennan and with the Senate firmly in the hands of Democrats, President George H.W. Bush appears to have taken both electoral gain and preserving political capital into account in deciding against selecting a movement conservative in 1990. Given that the last High Court vacancy had led to a raucous rejection of Robert Bork, President Bush sought a "kinder and gentler" nominee (and confirmation). In turn, Bush selected David Souter in part because he-in contrast to Borkhad a limited writing trail and presumably would have an easier time maneuvering through the confirmation process. As political scientist David Yalof (1999) writes, "In the twenty-two years since he had left private law practice, Souter had altogether avoided the subject of abortion rights, having never given a speech, written a law review article, or taken a public position of any kind on the correctness of Roe v. Wade. Thus by the administration's way of thinking, Souter was the 'anti-Bork."” The president considered other candidates who were thought to be more reliably conservative but "with the 1990 budget battle looming and critical midterm elections just a few months away," he settled on Souter (Yalof 1999, 191-92). Conservative activists 
were initially "cautiously optimistic" about the choice, but Souter's glowing comments about Justice Brennan during his confirmation hearings raised concern. One reasoned that rather than being a homerun, Souter was likely "a blooper single" (quoted in DeParle 1990). Still, the nominee provoked little dissent in the Senate, winning confirmation 90-9 on October 2, 1990.

In time, the bloc of O'Connor, Kennedy, and Souter would emerge as a powerful force on the Rehnquist Court; a force that consistently checked the implementation of the more conservative justices' constitutional vision. And as noted above, this result has been the principle reason why legal scholars have generally concluded that the work of this Court was limited in its successes. However, from the political perspective, assessments have been somewhat different. In addition to preserving political capital and appealing to moderate voters by avoiding confirmation battles, some evidence suggests that the decisions of this moderate bloc had positive electoral consequences for the Republican Party. Consider, for example, the electoral dynamics both immediately before and after the 1992 decision in Planned Parenthood $v$. Casey.

Indeed, while Casey clearly frustrated ideological conservatives like Richard E. Morgan, some high-profile Republican strategists actually found relief in the Court's ruling. After all, just three years earlier, when the Court's decision in Webster v. Reproductive Health Services seemingly signaled the end of Roe, abortion emerged as a central issue in gubernatorial races in New Jersey and Virginia. In both states, the Democrats won, reportedly because "thousands of Republicans and Republican-leaning independents" abandoned their party's pro-life candidate to support his prochoice opponent (Stone 1992; see also, Apple 1989). Mary Matalin, then the chief of staff for the Republican National Committee (RNC), believed that the July decision was particularly potent that election year. "It was a hydrogen bomb dropped into a conventional war." Soon after, RNC chairman Lee Atwater, long considered one of the GOP's sharpest strategists, began emphasizing a "big tent" philosophy for the party. "I want to make sure that everybody feels comfortable as Republicans, regardless of what their position on abortion is" (quoted in Rosenthal 1989). A year later, another GOP strategist stressed anonymously: "How the Republican Party handles some of its troubling fault lines, especially abortion, will depend on a certain amount of subtleness and even deviousness" (Toner 1990). However, it was thought that a decision overturning Roe in Casey would make such maneuvering difficult in 1992. As journalist Robin Toner reported, "The worst case scenario for Mr. Bush, in the view of many Democrats and some of his Republican friends, would involve the High Court overturning Roe at the height of the campaign. That coupled with the weak economy, could have a 
significant impact on the younger, suburban voters who are a critical swing vote in many Presidential elections" (Toner 1992a; see also, Toner 1992c).

As Toner suggests, not all Republican strategists thought a decision overturning Roe would have harmed the president's reelection chances. Veteran Republican consultant Eddie Mahe, for example, believed it would make the campaign "noisier" but would not "cause George Bush to lose if he might have otherwise won" (quoted in Toner 1992b). Others in the party simply didn't care. In challenging President Bush for the nomination, Patrick Buchanan declared: "I'm pro-life and I think my party should be pro-life. If that loses my party votes, so be it.” Democratic strategists gleefully looked forward to proving that possibility. As Frank Greer, an advisor to Bill Clinton, put it: "I believe George Bush has packed the Court and he's going to pay a political price for it. [A ruling reversing Roe] will push the issue front and center" (quoted in Toner 1992a).

But alas, the arguments never had to be tested. With Casey and other High Court decisions, Republican leaders, endeavoring to forge an electoral majority, never had to confront the consequences of a Court fully committed to a conservative counterrevolution in the law. Put another way, Republican presidential candidates could openly challenge Roe $v$. Wade, but never had to compete in a political environment where Roe was no longer the law, due to a ruling by a Republican-constructed Supreme Court. ${ }^{8}$ In turn, these candidates could rally social conservatives to the polls with Nixonian rhetoric, vowing to appoint justices who promised to strictly interpret the Constitution. ${ }^{9}$ By 2005, however, conservative Republicans appeared to have grown tired of simply running on the opportunity to overturn Roe. They seemed eager to make the Supreme Court appointments that would finally end Roe, finally discard the decision they had denounced for so long.

\section{Understanding Bush's Choices for the Court}

Before Justice O’Connor retired and Chief Justice Rehnquist died, it had been eleven years since the last vacancy to the Court. Fourteen years had passed since a Republican president had named a justice to the high bench. In the meantime, the three "wavering" justices had joined forces to decide Casey and had abandoned a strong conservative course on the major social issues of the day. Put another way, conservatives had been waiting for another opportunity to alter the dynamics of the Court for a long time, and they ultimately appeared to be quite unwilling to waste it on a nominee who raised ideological concerns. By 2005, moreover, the evidence suggests that conservatives believed the electoral math had changed; that overturning Roe would enhance rather than harm their party's position at the ballot box in future elections. 
The popularity of this belief should not be too surprising. After all, 2005 was a heady time for conservatives in Washington. President Bush had just won reelection by capturing over 62 million votes-more than any other presidential candidate in the nation's history — and had won 15 states with more than 59 percent of the vote. He had done so not by appealing to the "swing" voter but by pursuing a "base strategy" that highlighted a conservative message designed to turn out ideologically sympathetic voters in record numbers. ${ }^{10}$ And following the election, talk of a Republican realignment akin to that of 1896 filled the political air (Ceaser and Busch 2005; Toobin 2007, 264-65). In addition to Bush's victory, Republicans now controlled 55 Senate seats. Democrats appeared to be on the ropes. Six Democratic senators represented states that Bush had won decisively. With those seats in hand, Republicans would command a filibuster-proof margin in the Senate.

Given this level of success, conservatives were not in a compromising mood. After trusting previous Republicans presidents only to be disappointed once their nominees took their seats on the High Court, they were disinclined to give the president much leeway, even though it was widely assumed that he was committed to their cause. With his first selection of John Roberts (who earned a Segal score of .120), conservatives thought Bush hit a homerun, a grand slam. In their eyes, once confirmed a Justice John Roberts would make the Court more conservative than it had been with Sandra Day O'Connor. But then Chief Justice Rehnquist died. The Bush White House, which had always assumed Rehnquist's center chair would be the first to be vacated, acted swiftly, shifting Roberts's nomination from the associate slot to the newly vacant chief justice position.

As the search for another nominee began, President Bush appeared quite concerned about one of the few criticisms of his selection of Roberts. As none other than Justice O'Connor put it, “He’s good in every way, except he's not a woman” (quoted in Greenburg 2007, 213). First Lady Laura Bush concurred, saying she thought her husband should appoint a woman to the Court. The New York Times reported that the first lady's comments were actually a reflection of the president's own thinking; namely, that he understood the political symbolism of not replacing O'Connor with a woman the first time and was now focusing his search on finding a "conservative woman.” Unnamed Republicans listed the reasons, which included: Democrats would have more difficulty "demonizing" a female nominee; the confirmation process would be easier because Democrats would be less harsh in their attacks; and given that there was only one remaining woman on the Court it was the politically astute thing to do (Bumiller 2005). Within the White House counsel's office, staff lawyers were struck by the president's focus. As Greenburg (2007) writes, “Those lawyers-typically smart young conservatives who'd clerked for Thomas or Kennedy or Scalia or Rehnquist 
and opposed affirmative action like their former bosses-often were surprised to see the premium Bush put on diversity. 'I don't see any women on here,' Bush would say, with displeasure, if a list of executive branch nominees had only male names." And after Rehnquist died, the president pursued a similar path, rejecting the advise of lawyers in the counsel's office who urged him to select the runner-up to Roberts, Samuel Alito. ${ }^{11}$ Thinking politically, the president wanted either a woman or a minority. As his chief of staff Andy Card put it bluntly, “No white guys” (Greenburg 2007, 247-48, 245).

Bush's thinking may have confounded conservatives in the White House, but it should not surprise those knowledgeable of previous presidential selections for the Court (see Abraham 1999, Yalof 1999). Put in the simplest terms, Bush was not exclusively focused on ideology but interested in the political consequences of his selection as well. Choosing another "white guy" who met the conservative ideological test to fill the seat of the first woman justice for a second time might please movement conservatives but it would hardly do much to please the nation's soccer moms.

However, after scouring the pool of potential candidates, the choices were limited. In the end, the president settled on Harriet Miers, his White House counsel. Miers, who was overseeing the search, was not aware she was being considered for the position until Bush had nearly made up his mind. There was good reason why she - and many others-did not consider herself a serious candidate. While she had had a successful legal career, she did not possess the credentials of John Roberts or Samuel Alito (or any others who were seriously considered for the first vacancy). To the president, this lack of a track record was not important because he knew her, knew she was "tough as nails," a "pit bull in size six shoes" (quoted in Greenburg 2007, 264). In his mind, there was no chance Miers would waver once on the bench like O'Connor and Souter had done. Greenburg elaborates on the president's thinking, and how much he had Justice Souter on his mind when he made his decision:

Beyond the political expediency, Bush was also satisfied that she was capable. After all, his legal advisers had assured him she was qualified for the job. And ... Bush knew his friend was smart and tough enough to remain steadfast under pressure. . . . It's impossible to overstate how much the last concern drove Bush's thinking on Miers. He was determined not to repeat his father's mistake with Souter. . . . [His chief of staff Andy Card] didn't have to vouch for her conservatism the way [John] Sununu did for Souter. Bush thought Miers was in the mold of Thomas and Scalia, and he could be sure she would stay that way $(2007,265-66)$.

In addition to knowing her "heart," the president also knew that a Miers nomination was unlikely to provoke much of a battle from Senate Demo- 
crats. After all, Senate Minority Leader Harry Reid of Nevada first proposed Miers to the president, saying, "If you nominate Harriet Miers, you'll start with fifty-six voters" (quoted in Greenburg 2007, 256; see also, Toobin 2007, 283).

Conservatives didn't seem to care how well the president knew his nominee or how easy the confirmation would be. They were not prepared to risk this opportunity to shift the balance of the Court on another presidential hunch, on another Bush mistake. In turn, once word of the Miers nomination hit the street, conservatives set out to block it. William Kristol of the Weekly Standard was on the front lines of the attack, posting a column less than two and a half hours after Bush introduced Miers as his nominee. "I'M DISAPPOINTED, depressed and demoralized," wrote Kristol. To him, the president had failed to name someone with a "visible and distinguished constitutionalist track record" and instead selected someone with "no constitutionalist credentials." Kristol could not understand why Bush had "flinched from a fight on constitutional philosophy," by making a selection that "will unavoidably be judged as reflecting a combination of cronyism and capitulation" (2005).

While Senate Republicans largely held their fire on the Miers nomination, the conservative effort to block her bid for a seat on the High Court was picking up steam. As legal journalist Jeffrey Toobin explains, "Although the right tried to phrase its complaints about Miers as a matter of qualifications ... for movement conservatives, the problem ... [was] their own lack of certainty that she would follow their agenda on the Court" (2007, 292-93). (To be sure, she was perceived to be more moderate than Roberts, earning a Segal score of .270. $)^{12}$ Paul Weyrich, a longtime conservative activist on judicial issues, put it in perhaps the simplest terms. Adding Miers to the Republican-appointments of John Paul Stevens, O’Connor, Kennedy, and Souter, Weyrich explained that he "had had five 'trust-mes' in my long history" in Washington. "I'm sorry, but the president saying he knows her heart is insufficient" (quoted in Toobin 2007, 293). Weyrich and other movement conservatives wanted proof about Miers's convictions. But having spent most of her career as a corporate lawyer, she had little to offer.

Of course, in Bush's eyes, he was killing two birds with one stone in selecting Miers. First, by naming a woman, he was following the wise political course that would provoke little dissent from Democrats. And second, by choosing Miers he was filling the vacancy with someone who-in his view - was both deeply committed to the conservative cause and highly unlikely to become a victim of the "Greenhouse effect."," But to conservatives, his choice reminded them too much of Reagan's and his father's selection of "confirmable conservatives." To them, Miers was simply too risky, too much of an unknown commodity to fill the seat of a "moderate" 
swing justice. Too much like Souter. They wanted someone who would guarantee a more conservative Court.

Bush was not prepared to give up on Miers quickly. But outside circumstances had taken their toll on his job performance ratings, making it difficult for him to stick by his friend in the face of such resistance. In particular, his administration's response to Hurricane Katrina in late August was considered woefully inadequate and the War in Iraq was producing an alarming rise in violence and American causalities. Driven by these events, his approval rating dipped below forty percent. Added to this increasingly problematic climate, Miers consistently performed poorly in practice hearings and in individual meetings with senators. Unable to command easy conservative support and unwilling to engage in a battle with his ideological brethren who were suspicious of his nominee's conservatism and knowledge of the law, the president decided it was time to toss in the towel (Greenburg 2007, 282-84; Toobin 2007, 294-97). Her nomination would have to be withdrawn. After the president gave the word, Andy Card delivered the message. Three days later, the president announced the nominee conservatives wanted all along, Samuel Alito. He was another "white guy" who met the ideological test but who packed little electoral or symbolic punch. But as Toobin writes, the president's goal was "to select the most conservative possible Supreme Court justice," one who would please his ideological base $(2007,297)$. And this time, by naming Alito-who earned a Segal score of .100—he succeeded.

\section{Conclusion: The Highpoint of Conservatism}

During the period of conservative ascendance after the election of Ronald Reagan, I suggest that there was no other time when conservatives were as confident as they were in 2005 in their ability to alter the Court in a rightward direction. Perhaps the closest comparison came in 1986. Then, President Reagan, with reelection secure, elevated the most conservative sitting justice-William Rehnquist-to the Court's center chair and filled the vacancy with another committed ideologue, Antonin Scalia. With Republicans in control of the Senate and Democrats focusing their attack on Rehnquist, Scalia was confirmed without a dissenting vote. The Senate confirmed Rehnquist for chief justice as well, but by the fairly narrow margin of 65-33. The following year, Reagan appointed Robert Bork to fill the seat of the "swing” justice, Lewis Powell. However, with Democrats now in control of the Senate, Bork faced a tidal wave of opposition and was ultimately rejected by a vote of 42-58. As noted above, Reagan initially responded with confidence, selecting another movement conservative for the Powell seat. 
But when Douglas Ginsburg was forced to withdrawal his nomination, the president settled on the more confirmable Anthony Kennedy.

After the 2004 election, conservatives had the upper hand in the Senate. And they were eager to use their power. Even moderate Republicans were walking on eggshells. Consider, for example, the dilemma Arlen Specter of Pennsylvania, incoming chairman of the Senate Judiciary Committee, faced soon after Election Day. Specter had responded to a question about the future makeup of the Supreme Court by suggesting that the president needed to be cautious if given the opportunity to name a new justice. "When you talk about judges who would change the right of a woman to choose, overturn Roe v. Wade, I think that is unlikely. The president is well aware of what happened when a bunch of his nominees were sent up, with the filibuster. . . . And I would expect the president to be mindful of the considerations which I am mentioning” (quoted in Jordan 2004). Following those comments, Specter, a supporter of abortion rights who had only narrowly fought back a challenger from the right in the 2004 GOP Pennsylvania Senate primary, quickly became the target of conservatives intent on taking his expected chairmanship away from him. After two weeks of lobbying his Republicans colleagues, Specter survived the challenge. But in that space of time, it became clear that following the 2004 election the dynamics of judicial nominations had changed dramatically from the standpoint of conservatives. As Jeffrey Toobin writes, "In 1987, Robert Bork was defeated because he was too conservative for a Democratic Senate, and Specter still believed that the current Senate might vote down a nominee who was too conservative. In truth, the bigger risk for a George W. Bush nominee was if he or she was not conservative enough. To put it another way, Bork couldn't be confirmed because he opposed Roe v. Wade; in 2005, a nominee couldn't be selected unless he or she opposed Roe v. Wade" $(2007,266)$.

Moreover, any connection to the "wavering" Rehnquist Court justices - particularly Souter-seemed to doom potential nominees in the eyes of conservatives. For example, while the president's friend and attorney general Alberto Gonzales was thought to be "a hundred percenter" by conservative lawyers in the White House, conservatives outside the administration viewed him in different terms. A quip summed up their view: “'Gonzales' is Spanish for 'Souter”” (Toobin 2007, 268-69). Understanding this sentiment, White House lawyers convinced the president that conservatives would not celebrate Gonzales's selection. In turn, he never received serious consideration for an appointment to the Court in 2005, thus denying Bush the historic first of naming an American of Hispanic origin to the Court (Greenburg 2007, 188, 225-26, 246-47; Toobin 2007, 267-70).

To be sure, Republican thought on a more ideologically conservative Court was not united. After Miers's forced withdrawal, Republican 
Congressman Tom Davis of Virginia, considered one of the party's sharpest electoral strategists, warned of a "sea change in suburban voting patterns" if an unflinching conservative Court discarded Roe. "If Roe v. Wade is overturned," Davis speculated, "you're going to have a lot of very nervous suburban candidates out there. . I It's easy to say you're for a culture of life, but the answer is what do you do about it at that point.” Republican pollster Linda DiVall saw less of a suburban backlash on the horizon than Davis but still thought an anti-Roe decision would put the GOP further on the defensive in suburban areas (quoted in Balz 2005).

As noted above, such thinking was a minority view in the summer and autumn of 2005, and in turn, two movement conservatives made their way onto the bench. They are expected to contribute to the ideological advance of conservative principles, helping to secure George W. Bush's place in history. Of course, soon after Roberts and Alito took their seats, the president's poll numbers declined further, ultimately reaching historic lows. In 2006, Democrats took back control of both houses of Congress for the first time since the "Republican Revolution of 1994," and in 2008, Barack Obama easily defeated a Republican opponent handcuffed by voters' negative attitudes toward the Bush administration. After John McCain's defeat, talk of a Republican realignment was no longer heard. But conservatives know that their efforts to fill the Court with like-minded thinkers will have an enduring influence on constitutional law for years to come. Indeed, it may perhaps be one of the most significant legacies of the second Bush presidency.

\section{NOTES}

\footnotetext{
${ }^{1}$ See Sunstein 2005 for a discussion of these divisions within conservative judicial thought.

${ }^{2}$ Examples of the "regime politics" scholarship include: Clayton and Gillman 1999; Gillman and Clayton 1999; Graber 1993, 2005, Kahn and Kersch 2006, McMahon 2007, Peretti, 1999, and Whittington 2007.

${ }^{3}$ Segal's updated scores are available at: http://ws.cc.stonybrook.edu/polsci/jsegal/ qualtable.pdf (last accessed by author on October 30, 2008). See also Segal and Spaeth 2002. However, even the decision to choose Scalia before Bork-who were viewed as equally conservative in the Reagan White House-was motivated by political symbolism, a desire to appoint the first Italian American to the Court (Greenburg 2007, 43).

${ }^{4}$ As California governor, Reagan had signed even stronger pro-choice legislation.

${ }^{5}$ Max Friedersdorf to Jim Baker, Ed Meese, Mike Deaver, Fred Fielding, and Pen James, July 6, 1981; Michael Uhlmann to Edwin Messe, July 6, 1981, Reagan Presidential Library.

${ }^{6}$ Author interview with Reagan pollster Richard Wirthlin, July 2006.

${ }^{7}$ Steve A. Matthews to Special Project Committee, May 23, 1986, 7-8, Reagan Presidential Library.
} 
${ }^{8}$ However, the possibility of such a decision seemingly did play a role in Bush's defeat; see Abramowitz 1995.

${ }^{9}$ For an elaboration on the link between abortion and Republican Party politics, see Tushnet 2005 and Rosen 2006.

${ }^{10}$ See, for example, Frontline interviews with leading Republican strategists, retrieved by author in October 2008 at: http://www.pbs.org/wgbh/pages/frontline/shows/ architect/rove/2004.html.

${ }^{11}$ Harriet Miers was among the White House lawyers who supported Alito (Greenburg 2007, 247).

${ }^{12}$ At the same time, Segal's perceived qualifications scores highlight the concerns about Miers in comparison to Roberts and Alito. For these three, the perceived qualifications scores-ranging from 0 (least qualified) to 1 (most qualified)-were: Roberts (.970), Miers (.360), and Alito (.810).

${ }^{13}$ As Greenburg explains, the "Greenhouse Effect" is a coinage used "to describe the temptation a justice faces to drift left to appeal to the press, and to veteran New York Times Supreme Court reporter Linda Greenhouse in particular” (2007, 161).

\section{REFERENCES}

Abraham, Henry J. 1999. Justices, Presidents, and Senators: A History of the U.S. Supreme Court Appointments from Washington to Clinton. New York: Rowman \& Littlefield.

Abramowitz, Alan I. 1995. It's Abortion Stupid: Policy Voting in the 1992 Presidential Election. Journal of Politics 57:176-186.

Apple, R.W. 1989. Backlash at the Polls. New York Times, November 9.

Apple, R.W. 2000. Courting of Voting Bloc Poses Question of Motive. New York Times, August 2.

Balz, Dan. 2005. Rep. Davis Warns of Backlash if Roe v. Wade is Overturned. Washington Post, November 17.

Biskupic, Joan. 2005. Sandra Day O'Connor: How the First Woman on the Supreme Court Became Its Most Influential Justice. New York: Ecco/Harper Collins.

Bumiller, Elisabeth. 2005. Pillow-Talk Call for a Woman to Fill O’Connor Seat. New York Times, July 18.

Ceaser, James, and Andrew Busch. 2005. Red Over Blue: The 2004 Elections and American Politics. New York: Rowman \& Littlefield.

Clayton, Cornell W., and Howard Gillman, eds. 1999. Supreme Court Decision-Making: New Institutionalist Approaches. Chicago: University of Chicago Press.

DeParle, Jason. 1990. Souter Gives Little Comfort to Wary Conservatives. New York Times, September 17.

Gillman, Howard, and Cornell Clayton, eds. 1999. The Supreme Court in American Politics: New Institutionalist Interpretations. Lawrence: University Press of Kansas.

Gitenstein, Mark. 1992. Matters of Principle: An Insider's Account of America's Rejection of Robert Bork's Nominations to the Supreme Court. New York: Simon \& Schuster.

Graber, Mark A. 1993. The Nonmajoritarian Difficulty: Legislative Deference to the Judiciary. Studies in American Political Development 7:35-73.

Graber, Mark A. 2005. Constructing Judicial Review. American Review of Political Science 8:425-451. 
Greenburg, Jan Crawford. 2007. Supreme Conflict: The Inside Story of the Struggle for Control of the United States Supreme Court. New York: Penguin.

Greenhouse, Linda. 1987. Reagan Nominates Anthony Kennedy to the Court. New York Times, November 12.

Jordan, Lara Jakes. 2004. Specter Warns Bush on Picks for Top Court. Pittsburgh PostGazette, November 4.

Kahn, Ronald and Ken I. Kersch. 2006. The Supreme Court and American Political Development. Lawrence: University Press of Kansas.

Keck, Thomas M. 2007. Party Politics or Judicial Independence? The Regime Politics Literature Hits the Law Schools. Law \& Social Inquiry 32(2):511-544.

Kristol, William. 2005. Disappointed, Depressed and Demoralized: A reaction to the Harriet Miers nomination. Weekly Standard, October 3.

Maltz, Earl M. 2003. Anthony Kennedy and the Jurisprudence of Respectable Conservatism. In Rehnquist Justice: Understanding the Court Dynamic, ed. Earl M. Maltz. Lawrence: University of Kansas Press.

Massaro, John. 1990. Supremely Political: The Role of Ideology and Presidential Management. In Unsuccessful Supreme Court Nominations. Albany: State University of New York Press.

McMahon, Kevin J. 2007. Presidents, Political Regimes, and Contentious Supreme Court Nominations: A Historical Institutional Model. Law \& Social Inquiry 32(4):919954.

Morgan, Richard E. 2006. The Failure of the Rehnquist Court. The Claremont Review of Books 4(Spring):6.

Nemacheck, Christine L. 2007. Strategic Selection: Presidential Nomination of Supreme Court Justices from Herbert Hoover to George W. Bush. Charlottesville: University of Virginia Press.

Peretti, Terri. 1999. In Defense of a Political Court. Princeton, NJ: Princeton University Press.

Perry, Barbara A. 1991. A “Representative” Supreme Court? The Impact of Race, Religion, and Gender on Appointments. New York: Greenwood Press.

Rosen, Jeffrey. 2006. The Most Democratic Branch: How the Court Serve America. New York: Oxford University Press.

Rosenthal, Andrew. 1989. G.O.P. Leaders Urge Softer Line about Abortion. New York Times, November 10.

Savage, David. 1992. Turning Right: The Making of the Rehnquist Supreme Court. New York: John Wiley \& Sons.

Scherer, Nancy. 2005 Scoring Points: Politicians, Activists, and the Lower Federal Court Appointment Process. Stanford, CA: Stanford University Press.

Segal, Jeffrey A., and Harold J. Spaeth. 2002. The Supreme Court and the Attitudinal Model Revisited. New York: Cambridge University Press.

Selzer, Richard A., Jody Newman, and Melissa Voorhess Leighton. 1997. Sex as a Political Variable: Women as Candidates and Voters in U.S. Elections. Boulder, CO: L.P. Rienner.

Stone, Anne E.W. 1992. A Way Out for Republicans on Abortion. New York Times, April 23.

Sunstein, Cass R. 2005. Radicals in Robes: Why Extreme Right-Wing Courts Are Wrong for America. New York: Basic Books.

Toner, Robin. 1990. Why Some Republicans Lament Chief's Absence. New York Times, November 29.

Toner, Robin. 1992. New Worry for Bush. New York Times, January 22. 
Toner, Robin. 1992. Pennsylvania Abortion Case Adds an Edge To the Election. New York Times, January 26.

Toner, Robin. 1992. Ruling Eases a Worry for Bush, But Just Wait, His Critics Warn. New York Times, June 30.

Toobin, Jeffrey. 2007. The Nine: Inside the Secret World of the Supreme Court. New York: Doubleday.

Tushnet, Mark. 2005. A Court Divided: The Rehnquist Court and the Future of Constitutional Law. New York: W.W. Norton.

Whittington, Keith. 2007. Political Foundations of Judicial Supremacy: The Presidency, the Supreme Court, and Constitutional Leadership in U.S. History. Princeton.

Witt, Elder. 1986. A Different Justice: Reagan and the Supreme Court. Washington, DC: Congressional Quarterly Press.

Yalof, David Alistair. 1999. Pursuit of Justices: Presidential Politics and the Selection of Supreme Court Nominees. Chicago: The University of Chicago Press. 